Aquaculture

December 2018, Volume 497 Pages 278-286

http://dx.doi.org/10.1016/i.aquaculture.2018.07.067

http://archimer.ifremer.fr/doc/00453/56421/

(c) 2018 Elsevier B.V. All rights reserved.

\title{
Quality assessment of cryopreserved black-lip pearl oyster Pinctada margaritifera spermatozoa
}

\author{
Demoy-Schneider Marina ${ }^{1,{ }^{*}}$, Schmitt Nelly ${ }^{1}$, Le Pennec Gaël ${ }^{2}$, Suquet Marc ${ }^{3}$, Cosson Jacky ${ }^{4}$
}

${ }^{1}$ UMR 241 EIO, Université de la Polynésie Française, BP 6570, 98 704, Faa'a, Tahiti, France

${ }^{2}$ Laboratoire de Biotechnologie et Chimie Marines, Université Bretagne Sud, BP 9211656100 Lorient, France.

${ }^{3}$ Ifremer, UMR 6539 Lemar, Site expérimental d'Argenton, 29840 Argenton en Landunvez, France.

${ }^{4}$ Faculty of Fisheries and Protection of Waters, South Bohemian Research Center of Aquaculture and Biodiversity of Hydrocenoses, University of South Bohemia in Ceske Budejovice, 38925 Vodnany, Czech Republic.

* Corresponding author : Marina Demoy-Schneider, email address : marina.demoy-schneider@upf.pf

\begin{abstract}
:
High quality of sperm is essential to a high fertilization rate, especially post- cryopreservation. Assessment of sperm integrity, motility and energy reserves before cryopreservation is necessary for selection of milt with optimal fertilizing potential. We describe the effect of cryopreservation on the quality of black-lip pearl oyster, Pinctada margaritifera var. cumingii sperm. Evaluated quality indices of fresh and frozen/thawed $P$. margaritifera spermatozoa, included morphology, ultrastructure and motility characteristics relative to the energy content (ATP) and its capacity to be sustained by mitochondrial respiration. Morphology and ultrastructure were quantitatively evaluated using images obtained by optical microscopy assisted by the Image $\mathrm{J}$ software and TEM, respectively. Sperm motility was assessed using Image $\mathrm{J}$ software combined with a computer assisted sperm analysis plugin adapted for assessing $P$. margaritifera spermatozoa. Other sperm quality parameters evaluated included $\mathrm{O}_{2}$ consumption, ATP content, and creatine kinase activity. Frozen/thawed spermatozoa exhibited damage to the head but retained a compact spherical shape. Sperm motility indicators showed a significant decrease in quality resulting from the freeze/thaw process. The percent of motile cells was $54 \%$ compared to $84 \%$ in fresh sperm, $\mathrm{O}_{2}$ consumption was 4.8 compared to 44 nanomol $\mathrm{min}^{-1}$, ATP content was $0.72 \mathrm{nmol} / 10^{9}$ spermatozoa in the activating medium compared to $4.54 \mathrm{nmol} / 10^{9}$ spermatozoa, and creatine kinase activity was $9.06 \times 10^{-5} \mathrm{IU} \mathrm{mg}^{-1}$ protein compared to $12.5 \times 10^{-5} \mathrm{IU} \mathrm{mg}^{-1}$ protein.
\end{abstract}

The cryopreservation protocol allowed obtaining an acceptable motility rate after thawing, confirming the predictive value of sperm motility measurements before cryopreservation in terms of their ability to withstand freezing process. 


\section{Highlights}

- Quality of the frozen/thawed black-lip pearl oyster Pinctada margaritifera spermatozoa. Progress to an efficient cryoconservation method for $P$. margaritifera spermatozoa. Preservation of $P$. margaritifera through the durable development of the pearl oyster culture in French Polynesia.

Keywords : Spermatozoa quality, Cryopreservation, Pinctada margaritifera, Motility, Metabolism, CASA 


\section{Introduction}

76

77

In French Polynesia, the black pearls produced by the endemic black-lip pearl oyster Pinctada margaritifera, are valued for characteristics such as their highly polished aspect and variety of colors. This economic asset needs to be preserved and perpetuated through development of pearl oyster culture and sustainable production. In French Polynesia, black pearl production currently relies almost exclusively on the collection of spat of wild $P$. margaritifera, making aquaculture and marketing dependent on natural resources.

Gamete cryopreservation is a potentially powerful technique for preservation of black-lip pearl oyster lineages to safeguard its biodiversity. Several research programs have been developed to define biological and physiological parameters of black-lip pearl oyster spermatozoa in various swimming media. These studies have shown that $P$. margaritifera spermatozoa possess characteristics of movement, motility, mitochondrial respiration rates, and ATP utilization similar to those of other bivalve species (Demoy-Schneider et al. 2012, 2014). Motility of black-lip pearl oyster spermatozoa develops gradually when spermatozoa are transferred into alkaline sea water with the percentage of motile cells increasing and motility lasting for several minutes. The fully motile spermatozoa exhibit planar and sinusoidal flagellar waves in a homogeneous fashion. The swimming tracks are almost circular with head trajectories describing arcs interspersed with short linear segments. Spermatozoa held at $4^{\circ} \mathrm{C}$ retain potent motility for several days and can be subsequently activated by alkaline swimming medium. Mitochondrial respiration rates and ATP utilization are closely bound to the activation of motility. The respiration rates are strongly increased and ATP is more rapidly consumed immediately after motility activation (Demoy-Schneider et al. 2012, 2014). 

applied to teleost (Martínez-Páramo et al. 2017), sea urchins (Adams et al. 2004a) and bivalve mollusks such as Crassostrea gigas (Bougrier and Rabenomanana 1986; Adams et al. 2004b; Dong et al. 2005), Crassostrea virginica (Paniagua-Chavez and Tiersch 2001; Yang et al. 2012), Crassostrea tulipa (Yankson and Moyse 1991), Haliotis diversicolor supertaxa (Gwo et al. 2002), Pinctada fucata martensii (Kawamoto et al. 2007; Narita et al. 2007, 2008), Mytilus galloprovincialis (Di Matteo et al. 2009; Liu et al. 2016), Argopecten purpuratus (Espinoza et al. 2010), Ostrea edulis (Horváth et al. 2012), Pecten maximus (Suquet et al. 2016), and Pinctada angulata (Riesco et al. 2017).

Lyons et al. (2005) and Acosta-Salmon et al. (2007) reported the effect of several

109 cryoprotectant additives on P. margaritifera sperm motility after freeze/thawing and Hui et al.

110 (2011) reported reduced viability of spermatozoa after freeze/thawing. However, other studies

111 focused cryopreservation aspects in different species leading to varied sperm survival rates

112 after thawing, and suggested limitations of using only a single trait to define sperm quality

113 (Holt and Van Look 2004). Complementary studies such as those investigating movement

114 tracking using computer assisted sperm analysis (CASA), cell integrity, and activity of 115 enzymes involved in the regeneration of ATP, are expected to lead to better understanding of $116 P$. margaritifera sperm quality prior to cryopreservation. Sperm motility is one of the most 117 important criteria in sperm quality, especially in predicting its fertilization ability (Cosson et 118 al., 2008a and b).

119 In French Polynesia, hatchery practices have been developed in the same oyster species, and 120 some fertilization assays using frozen/thawed spermatozoa show fertilization rates similar to 121 those obtained using fresh spermatozoa (Hui et al. 2009, 2011). In this context, $P$. margaritifera sperm cryopreservation will prove beneficial to black pearl commercial interest.

123 The goals of sperm preservation are to maintain the gametes of individuals selected for high- 
124 growth potential and/or the color of their pearls (Ky et al. 2015) along with easier availability

125 and lower risks compared to those incurred in maintenance of broodstock. In addition, the

126 freezing of gametes assures the ex-situ preservation of genetic diversity of the populations of

127 wild black-lip pearl oysters threatened with standardization by the transfer of the juveniles 128 among Polynesian islands (Arnaud-Haond et al. 2004). Sperm freezing thus present a means

129 of maintaining the economic potential and safety of black-lip pearl oyster culture, knowing 130 that the black pearl represents the second economic resource after tourism in French 131 Polynesia.

The objective of the study was to describe the quality of fresh and frozen/thawed

134 black-lip pearl oyster spermatozoa assessing parameters such as percent of intact spermatozoa

135 and spermatozoa ultrastructure, membrane integrity, motility and, metabolism.

136

$137 \quad 2 . \quad$ Material and methods

$138 \quad 2.1 . \quad$ Oysters and sperm collection

All experiments were carried out using black-lip pearl oysters reared in the Takapoto

141 Atoll, Tuamotu Archipelago, French Polynesia, located $560 \mathrm{~km}$ east of Tahiti (14³2’ S

$142145^{\circ} 14^{\prime} \mathrm{W}$ ) until the age of 24 months and an average diameter of $10.5 \pm 2.1 \mathrm{~cm}$ (Pouvreau et

143 al. 2000). During the natural reproduction period, pearl oysters were collected from suspended

144 long-line culture and shipped at $25^{\circ} \mathrm{C}$ on a $1 \mathrm{~h}$ flight to the laboratory (UMR $241 \mathrm{EIO}$,

145 University of French Polynesia, Tahiti, French Polynesia). Immediately upon arrival, oysters

146 were immersed in filtered seawater tanks $\left(25^{\circ} \mathrm{C}, \mathrm{pH} 8.1\right)$ for $24 \mathrm{~h}$ without feeding, prior to

147 experimental use. 

muscle. Milt was manually collected by micropipette after natural release from the gonopore.

150 The semen (dry sperm) was stored for a maximum of $2 \mathrm{~h}$ in test tubes at $4.0^{\circ} \mathrm{C} \pm 0.5^{\circ} \mathrm{C}$ 151 before measurements.

\section{2. $\quad$ Swimming medium}

For a rapid evaluation of sperm motility, an aliquot of sperm from each male was transferred at a dilution of 1:2000 (v/v) in a saline activating medium composed of $\mathrm{NaCl}, 19.5$ $\mathrm{g} \mathrm{L}^{-1}$; glycine, $6.25 \mathrm{~g} \mathrm{~L}^{-1} ; \mathrm{CaCl}_{2}, 0.15 \mathrm{~g} \mathrm{~L}^{-1} ; \mathrm{MgSO}_{4}, 0.19 \mathrm{~g} \mathrm{~L}^{-1}$ and tris-aminomethane, $2.42 \mathrm{~g}$ $\mathrm{L}^{-1}\left(\mathrm{DCSB}_{4}\right)$ (adapted from Paniagua-Chavez et al. 1998) with final $\mathrm{pH}$ adjusted to 8.2 according to Bougrier and Rabenomanana (1986). Chemical compounds were purchased from Fisher Scientific Labosi (Elancourt, France), VWR-Prolabo (Fontenay sous Bois, France) and Sigma-Aldrich (Saint Quentin Fallavier, France).

162 The analyses were performed on 28 males. The sperm of 18 presenting sperm motility $>70 \%$, was used for cryopreservation.

\subsection{Cryopreservation}

The cryoprotectant additive mixture was adapted from the method of Hui et al.

168 (2009), using a solution of $0.7 \mathrm{M}$ trehalose, $0.8 \mathrm{M}$ dimethyl sulfoxide and 10\% oyster 169 hemolymph collected from the mantle cavity. According to Acosta-Salmon et al. (2007), milt

170 was slowly mixed into the cryoprotectant additive mixture at a 1:10 (v/v) dilution and $350 \mu \mathrm{L}$

171 of the mixture was placed in $500 \mu \mathrm{L}$ semen straws (IMV, France). Samples remained on ice

172 less than 10 min between milt dilution and initiation of the cooling process. Cooling was 
173 conducted in liquid nitrogen vapor: straws were placed on a floating tray $3 \mathrm{~cm}$ above the

174 liquid nitrogen surface for $12 \mathrm{~min}$ before immersion. The straws remained at least $2 \mathrm{~h}$ in the

175 liquid nitrogen. Subsequently, they were thawed by incubation in a water bath for $30 \sec 25^{\circ}$

176 C.

$178 \quad 2.4 . \quad$ Sperm preparation and processing

$179 \quad$ 2.4.1. Sperm concentration

180

The sperm concentration of each frozen/thawed sample was evaluated by counting

182 the cells at 400x (Leica, DM 2000) magnification after 1:2000 (v/v) dilution in filtered

183 seawater. Images were recorded using a numeric digital video camera (Leica, DFC 425C)

184 followed by image analysis. The sperm suspension was introduced in a Malassez's 185 hemacytometer and six $0.05 \mathrm{~mm}^{2}$ rectangular areas were randomly photographed and 186 analyzed using ImageJ 1.45 software (https://imagej.nih.gov/ij/) under the parameters 187 described in Table 1 to calculate the mean concentration as spermatozoa $\mathrm{mL}^{-1}$.

\subsubsection{Sperm morphology and ultrastructure}

192 area, Crofton perimeter, Feret diameter and circularity were determined using Image J

193 software. In an intact particle with an uninterrupted surface, the mean Feret diameter is

194 proportional to the particle perimeter. Circularity provides indications of the particle shape

195 and is defined as $4 \pi \times \mathrm{a} /(\mathrm{p})^{2}$, in which " $\mathrm{a}$ " is the particle area and " $\mathrm{p}$ " is the particle

196 perimeter. This parameter ranges between 0 and 1 , the latter corresponding to a perfect round 
197 particle. The calibration parameters were the same as for the evaluation of sperm 198 concentration (Table 1). and frozen/thawed sperm samples from three oysters randomly selected. Fresh sperm was 202 diluted 1:20 (v/v) in regular filtered seawater. Frozen/thawed as well as fresh spermatozoa were allowed to settle at room temperature $\left(25^{\circ} \mathrm{C}\right)$ for $30 \mathrm{~min}$ to eliminate the cryoprotectant additive mixture without centrifugation. The cryoprotectant additive supernatant was discarded and the frozen/thawed spermatozoa were diluted 1:20 (v/v) in regular filtered seawater. Motility was assessed in the $\mathrm{DCSB}_{4}$ activating medium as previously described 207 (Demoy-Schneider et al., 2012). Then, $1 \mathrm{~mL}$ of fixative (5\% glutaraldehyde in filtered 208 seawater) was slowly added under gentle stirring, to $1 \mathrm{~mL}$ of the diluted sperm sample. After complete homogenization, the samples were incubated at $4{ }^{\circ} \mathrm{C}$ overnight to achieve optimal fixation. Fixative supernatant was removed and samples were washed twice with $2 \mathrm{~mL}$ sodium cacodylate buffer ( $\mathrm{pH}$ 7.3, $0.1 \mathrm{M}$ in filtered seawater) with overnight settling down at $2124^{\circ} \mathrm{C}$ after each washing. After the second washing, sodium cacodylate supernatant was 213 removed and $2 \mathrm{~mL}$ of $70 \%$ ethanol was added to the fixed spermatozoa. After a complete 214 dehydration in ascending series of alcohol, spermatozoa were embedded in Spurr's resin 215 following manufacturer's recommendations (EM0300, Sigma-Aldrich, Saint Quentin 216 Fallavier, France). Ultra-thin sections $(60 \mathrm{~nm})$ were contrasted with uranyl acetate and lead 217 citrate before observations using a JEOL JEM-1400 transmission electron microscope.

\subsubsection{Sperm motility assessment}


Motility characteristics of fresh and frozen/thawed spermatozoa were obtained from

222 video records. Fresh sperm was diluted 1:100 (v/v) while frozen/thawed sperm was diluted $2231: 10(\mathrm{v} / \mathrm{v})$, using $\mathrm{DCSB}_{4}$ as activating solution in test tubes for $4 \mathrm{~min}$, at the end of the 224 capacitation phase, when maximum values of sperm movement are observed (Boulais et al. 2018) and reach full sperm motility. Subsequently, $2 \mu \mathrm{L}$ of the suspension was immediately 226 transferred into a $50 \mu \mathrm{L}$ drop of $\mathrm{DCSB}_{4}$ onto a glass slide and covered with a cover-slip 227 (25 000x final dilution) at room temperature. Microscopy observations were conducted, at the 228 level of the cover-slip, 4 min post-activation using a LEICA DM2000 phase contrast 229 microscope under 400x magnification. Ten-second video records were filmed with a LEICA 230 DFC425C video camera (25 frames $\sec ^{-1}$ ). Sperm movement was analyzed using the computer 231 assisted sperm analysis (CASA) plug-in for ImageJ software (Wilson-Leedy and Ingermann 232 2007) initially developed for fish spermatozoa and adapted to the black-lip pearl oyster 233 spermatozoa. Sperm motility percentage, straight line velocity (VSL, $\mu \mathrm{m} \mathrm{sec}{ }^{-1}$ ), velocity of average path (VAP, $\mu \mathrm{m} \mathrm{sec}{ }^{-1}$ ) and linearity (LIN, as a measure of a curvilinear path, $100 \mathrm{x}$ VSL/VAP) were analyzed. The calibration parameters used for motility measurements are presented into the Table 2. A minimum of 50 spermatozoa were tracked for each video record.

\subsection{Sperm metabolism and energy stores}

Mitochondrial respiration rates of the sperm suspensions were assessed for fresh and

242 frozen/thawed spermatozoa, by continuous recording of the oxygen concentration, during 10

243 min in filtered seawater or $\mathrm{DCSB}_{4}$ with a highly sensitive calibrated Clark electrode (Rank

244 Brothers, Cambridge, England) according to Pacey and Bentley (1993). To determine the $\mathrm{O}_{2}$

245 consumption, $50 \mu \mathrm{L}$ of dry black-lip pearl oyster sperm $\left(15 \times 10^{9}\right.$ spermatozoa $\left.\mathrm{mL}^{-1}\right)$ was

246 diluted in $1 \mathrm{~mL}$ of the swimming solution $\left(\mathrm{DCSB}_{4}\right)$ to a final concentration of $7.5 \times 10^{8}$

247 spermatozoa $\mathrm{mL}^{-1}$ in a tightly closed chamber. The sperm suspension was kept as homogenous 
as possible using a magnetic stirrer. A $100 \%$ reading in $\mathrm{O}_{2}$ concentration $\left(253 \mathrm{nmol} \mathrm{mL}^{-1}\right)$ indicated to the swimming medium in equilibrium with the air at $25{ }^{\circ} \mathrm{C}$ while $0 \% \mathrm{O}_{2}$ concentration in the swimming medium was obtained by addition of few crystals of sodium dithionite at the end of the measurement period (Demoy-Schneider et al. 2012).

Adenosine 5' triphosphate (ATP) content of the milt was estimated as we previously described (Demoy-Schneider et al. 2012). Briefly, ATP content was assessed in triplicate for fresh and frozen/thawed sperm, by bioluminescence (ATPlite-M kit according to the manufacturer instructions, Perkin Elmer Life and Analytical Sciences, Villebon sur Yvette, France). The ATP concentration was evaluated at 4 min post-activation, when spermatozoa were fully motile. Sperm dilution was, adjusted to a final concentration of $75 \times 10^{6}$ spermatozoa $\mathrm{mL}^{-1}$. Luminescence intensity was assessed using a Spectrafluor Plus luminometer (Tecan Group Ltd., Maennedorf, Switzerland) with the XFluor4 software (Genios Pro, Tecan Group Ltd., Maennedorf, Switzerland). The emitted light was in direct proportion to the ATP content; the latter was calculated using a standard curve [relative luminescence units versus ATP content $\left.\left(\mathrm{nmol} \mathrm{mL} \mathrm{L}^{-1}\right)\right]$.

successive coupled enzyme reactions, with the final measured compound being nicotinamide adenine dinucleotide phosphate (NADPH). In the present study, NADPH production was measured spectrophotometrically at $340 \mathrm{~nm}$, using the ECPK-100 kit (EnzyChrom ${ }^{\mathrm{TM}} \mathrm{CK}$ Assay Kit, Bioassay Systems, Hayward, CA, USA) and was proportional to the creatine kinase activity. As a positive control, a piece of chicken breast muscle freshly excised was used. One gram of chicken muscle was homogenized using an Ultraturax homogenizer in a threefold volume of lysis buffer (Tris hydroxyl amino methane $0.1 \mathrm{M}$, EDTA $1 \mathrm{mmol}$ ) at $4^{\circ}$ 
$273 \mathrm{C}$ for $1 \mathrm{~min}$. A $500 \mu \mathrm{L}$ volume of fresh or frozen/thawed sperm was diluted in $1.5 \mathrm{~mL}$ of lysis 274 buffer and homogenized in the same conditions as previously described for the chicken 275 muscle. The homogenized tissue was centrifuged at $20000 \mathrm{x}$ g for $30 \mathrm{~min}$ at $4^{\circ} \mathrm{C}$ (adapted 276 from Bacou 1972), and $10 \mu \mathrm{L}$ of each supernatant were used for creatine kinase activity 277 quantification. Enzyme reactions were performed in 96-well flat bottom micro-plates. A 100 $278 \mu \mathrm{L}$ volume of kit reaction medium was prepared and immediately added to $10 \mu \mathrm{L}$ of 279 supernatant. The micro-plates were shaken for $5 \mathrm{~min}$ at $25^{\circ} \mathrm{C}$ and then incubated at $37^{\circ} \mathrm{C}$ 280 for $10 \mathrm{~min}$. Measurements were performed in triplicate, $10 \mathrm{~min}$ and $40 \mathrm{~min}$ after mixing, at $281340 \mathrm{~nm}$ (UV) using an Infinite M200 spectrophotometer (TECAN, Austria). We chose to express creatine kinase activity as $\mathrm{IU} \mathrm{mg}^{-1}$ of protein, to facilitate 283 comparison with published results of studies in other species. Sperm total proteins were 284 prepared with the lysis buffer provided with the kit and quantified using the method of Lowry et al. (1951).

\subsection{Data analysis}

Data are presented as mean \pm SEM obtained from the analysis of independent sperm samples. Percentages were arcsine square root transformed before further analysis. To quantify the effect of cryopreservation on the percentage of motile spermatozoa, on the spermatozoa movement and on the morphological characteristics, means were compared using 293 a two-way analysis of variance (ANOVA). When significant differences were observed $(P<$ 0.05) Shapiro Wilk and Fisher tests were used.

\section{Results}




\subsection{Sperm concentration}

299

300

301

302

303

304

305

306

307

The total volume of dry sperm collected from each animal was individual-dependent with a mean of $1.00 \pm 0.25 \mathrm{~mL}$. The mean sperm concentration was $16.1 \pm 1.2 \times 10^{9}$ spermatozoa $\mathrm{mL}^{-1}(\mathrm{n}=28)$.

\subsection{Effect of cryopreservation on spermatozoa morphology and ultrastructure}

Most assessed morphological parameters of frozen/thawed sperm showed a significant difference $(P<0.05)$ from those of fresh (Table 3). Area, Crofton perimeter, and Feret diameter values were $61 \%, 39 \%$ and $35 \%$ lower, respectively. No significant differences were observed in the circularity parameter and the Feret diameter/Crofton perimeter ratio.

Fifty TEM images were analyzed. The black-lip pearl oyster spermatozoon possessed a spherical head and a short mid-piece. The dense spherical nucleus occupied most of the head and exhibited an anterior depression located in the sub-acrosomal zone and a posterior depression at the basal pole. The proximal centriole was inserted centrally into a ring (Fig 1a) comprising four mitochondria (Fig. 1b). The distal centriole was located in the mid-piece, near the base of the flagellum (Fig. 1a). A flat cap was apparent over the acrosome, and the sub-acrosomal space was filled with a dense material (Fig. 1c). The axoneme comprises 9 peripheral +2 central microtubules (Fig.1d, 1f).

Damage to the plasma membrane of frozen/thawed spermatozoa was observed. The membrane appeared swollen on some portions of the head (Fig. 1e, 1f). Minimal differences from fresh spermatozoa were noted in the acrosome (Fig. 1g) and mitochondria (Fig. 1h). The nucleus and chromatin did not differ from those of fresh spermatozoa. The most prevalent difference was related to the flagellum: the latter was not visible in nearly 
$80 \%$ of frozen/thawed spermatozoa TEM images possibly because of the fragilization of the

325 head/tail junction resulting from the treatment applied for TEM visualization (Fig. 1e). When 326 the flagellum was observable, proximal and distal centrioles were located in the same 327 position as in fresh spermatozoa. The axoneme appeared to have a similar pattern that of 328 the fresh spermatozoa, with peripheral and central microtubules (Fig. 1h).

\subsection{Effect of cryopreservation on sperm motility and movement}

Fresh, as well as frozen/thawed spermatozoa were non-motile in regular seawater, but motility was activated in a large proportion of cells in $\mathrm{DCSB}_{4}: 84.7 \%$ of fresh cells and $54.4 \%$ of frozen/thawed spermatozoa (Fig. 2). In addition, the motility of fresh and frozen/thawed spermatozoa showed a significant linear correlation $(P<0.05)\left(\mathrm{R}^{2}=0.59\right)$. The more motile the spermatozoa are before cryopreservation, the more motile they are after thawing (Fig. 3). Velocity parameters for fresh sperm were $66.6 \mu \mathrm{m} \mathrm{sec}^{-1}$ for VSL and 165.7

$338 \mu \mathrm{m} \mathrm{sec}^{-1}$ for VAP. Linearity was calculated at $40.6 \%$. After freeze/thaw, $35 \%$ lower sperm motility $(P<0.05)$ and $20 \%$ lower VAP $(P<0.05)$ compared to fresh was observed. No significant difference was observed in VSL and LIN values of fresh and frozen sperm for any treatment (Table 4).

\subsection{Effect of cryopreservation on sperm metabolism and energy stores}

0.05) $\mathrm{O}_{2}$ consumption compared to cryopreserved (44.4 vs. $6.7 \mathrm{nmol} \mathrm{min}^{-1} / 10^{9}$ spermatozoa). nmol $\min ^{-1} / 10^{9}$ after freeze/thaw, a difference of $89 \%(P<0.05)$ (Fig. 4a). 

content, with and without activation. Motility activation makes the ATP content decrease from 34.50 to $4.54 \mu \mathrm{mol} / 10^{9}$ spermatozoa for fresh sperm and from 13.30 to $0.72 \mu \mathrm{mol} / 10^{9}$ spermatozoa for frozen/thawed sperm (Fig. 4b). For frozen/thawed spermatozoa, this represents a difference of $61.4 \%$ and $84.1 \%$, in natural seawater and $\mathrm{DCSB}_{4}$, respectively, 354 compared to fresh cells. creatine kinase activity was in the range of $20.95 \pm 1.35 \mathrm{IU} \mathrm{mg}^{-1}$ of muscle protein. The mean protein content of the spermatozoa was $151.70 \pm 23.70 \mathrm{~g} \mathrm{~L}^{-1}$, corresponding to $9.48 \pm 1.48 \mathrm{mg}^{-}$ $1 / 10^{9}$ spermatozoa, with mean sperm concentration of $16 \times 10^{9}$ spermatozoa $\mathrm{mL}^{-1}$.

359 Compared to fresh spermatozoa, significantly lower $(P<0.05)$ creatine kinase activity was 360 observed after freeze/thawing, at $12.5 \mathrm{IU} \mathrm{mg}^{-1}$ in fresh spermatozoa and at $9.06 \mathrm{IU} \mathrm{mg}^{-1}$ in 361 frozen/thawed cells (Fig. 4c).

\section{Discussion}

Fertilization of an oocyte is dependent on the quality of spermatozoa, specifically their motility (Cosson et al. 2008a, b) and metabolic activity (mitochondrial respiration, ATP 367 hydrolysis) (Boulais et al. 2015, 2017; Suquet et al. 2016). It has been reported that 368 cryopreservation may induce oxidative stress ( $\mathrm{Li}$ et al. 2010a; Shaliutina-Kolešová et al. 369 2015) damaging spermatozoon structure (Gwo et al. 2003; Paniagua-Chavez et al. 2006; 370 Suquet et al. 2016) and decreasing motility (Dong et al. 2005; Gwo et al. 2002; Kawamoto et 371 al. 2007; Riesco et al. 2017; Suquet et al. 2016) and fertilizing capacity (Boulais et al. 2017;

372 Dong et al. 2005; Gwo et al. 2002; Narita et al. 2008; Paniagua-Chavez and Tiersch. 2001; 373 Riesco et al. 2017). 
376 of oysters spermatozoa: a round shape head and a short mid-piece containing four

377 mitochondria, a flat acrosome, an axoneme with $9+2$ microtubules and, in contrast to 378 mammalian sperm, no accessory structures. These observations are in accordance with the 379 spermatozoa ultrastructure described in many other oyster species (Yurchenko 2012).

380 Area and Crofton perimeter have been previously used to estimate the quality of 381 frozen/thawed European eel spermatozoa (Asturiano et al. 2007) and frozen-thawed Japanese 382 oyster Crassostrea gigas larvae (Suquet et al. 2012a). No significant variation was observed 383 in the circularity parameter, suggesting that the spermatozoa kept a circular contour shape 384 after the freeze/thawing process. The Feret diameter/Crofton perimeter ratio did not 385 significantly differ from fresh, indicating that the particle shape remained intact after thawing.

386 On the other hand, we observed that the area of frozen/thawed spermatozoa was $61 \%$ lower 387 than that of fresh sperm. Crofton perimeter was 39\% lower and Feret diameter $35 \%$ lower, 388 probably associated with spermatozoon head damage (Table 3). The TEM micrographs 389 revealed that the plasma membrane was disrupted at the head-tail junction, in the 390 mitochondria region. We observed the absence of visible flagella, for a high number of 391 frozen/thawed spermatozoa. The complete flagellum may not have been included in the 392 photographic frame. Flagella may also have become detached during sample processing. In 393 addition, the accumulation of swimming spermatozoa near surfaces, obscuring the flagella

394 should be considered, as has been shown in several species (Cosson et al. 2003). This 395 accumulation may partly explain, why the mean $\%$ of motile cells remains of $54 \%$ in motility 396 trials when about $80 \%$ of spermatozoa have lost their flagellum after freezing.

397 We observed swelling in the plasma membrane after the freeze/thaw process. Similar damage 398 was reported in the Chilean scallop Argopecten purpuratus (Espinoza et al. 2010), blue mussel 
Mytilus galloprovincialis (Liu et al. 2016) and great scallop Pecten maximus (Suquet et al.

400 2016).

401 Damage caused by the freeze-thaw process may differ with species. Studies of other species reported that alterations in morphology of frozen/thawed spermatozoa are clearly visible. Kurokura et al. (1990) observed abnormalities of the pacific oyster acrosome and mid-piece and Gwo et al. (2003) observed alterations inside the chromatin. Suquet et al. (2016) noted variable damage in samples of the great scallop: in some spermatozoa, little or no damage was observed at the level of acrosome and mitochondria while for others, alterations were considerable.

The anomalies we observed in the black-lip pearl oyster morphological parameters (area, 409 diameter and perimeter), suggests alterations in the shape of spermatozoa resulting from the 410 freeze/thaw process, although the circularity parameter and Feret diameter/Crofton perimeter ratio did not differ significantly from fresh. These results confirmed that, despite the addition

412 of a cryoprotectant agent, spermatozoa undergo significant morphological and ultrastructure 413 damage with freezing, which could influence their quality after thawing.

For several marine species, sperm membrane integrity is closely related to motility (Paniagua-Chavez et al. 2006; Merino et al. 2011). The CASA plug-in developed for Image J

417 (Wilson-Leedy and Ingermann 2007) has long been used to describe sperm motion and 418 provides information for quality assessment of semen of many species, including oysters 419 (Wilson-Leedy and Ingermann 2007; Amann and Waberski 2014; Boulais et al. 2015; 420 Aberkane and Iguer-ouada 2016; Suquet et al. 2016; Boulais et al. 2017). We observed that 421 movement of frozen/thawed black-lip pearl oyster spermatozoa differed from that of fresh. 422 This is in accordance with Acosta-Salmon et al. (2007), who reported that motility of 423 frozen/thawed sperm was $65 \%$ lower than the values recorded for fresh sperm, in the same 
species. Many other studies of mollusk species have also shown significantly lower sperm motility as a result of the freeze/thawing process. In 2016, Suquet et al. assessed the effect of cryopreservation on the percentage of motile frozen/thawed spermatozoa and reported motility values versus controls, of $65 \%$ in the Pacific oyster; from 50 and $60 \%$ in the blue mussel Mytilus galloprovincialis, eastern oyster Crassostrea virginica or Chilean scallop Argopecten purpuratus; and from 20 and $35 \%$ in the pearl oyster Pinctada fucata martensii, 430 great scallop Pecten maximus, and flat oyster Ostrea edulis. We did not observe any 431 significant difference in the motility duration $(\sim 10 \mathrm{~min})$ in frozen/thawed black-lip pearl 432 oyster spermatozoa compared to fresh, in contrast to results obtained by Kawamoto et al. 433 (2007) for P. fucata martensii who reported significantly lower motility duration in 434 frozen/thawed spermatozoa. Our results suggest that when fresh spermatozoa are fully motile, 435 they remain still motile after thawing, which shows the predictive value of motility 436 measurements of sperm before freezing in their ability to resist freezing process. This 437 indicates that the spermatozoa that survived the freeze/thaw process possess sufficient energy 438 reserves to show activity similar to fresh sperm. In the active spermatozoa, we observed 20\% lower VAP in frozen/thawed sperm 440 compared to fresh. Suquet et al. (2016) reported $75 \%$ lower velocity in frozen/thawed 441 spermatozoa of the great scallop compared to fresh. Linhart et al. (2005) also reported 442 significantly lower VAP (44\% difference) in cryopreserved Cyprinus carpio spermatozoa, and 443 Psenicka et al. (2008) found 35\% lower VAP in frozen/thawed Acipenser ruthenus 444 spermatozoa. Straight-line velocity (VSL) was measured in fresh and frozen/thawed black-lip 445 pearl oyster spermatozoa, at $66.6 \pm 2.7 \mu \mathrm{m} \mathrm{sec}^{-1}$ and $62.5 \pm 4.8 \mu \mathrm{m} \mathrm{sec}^{-1}$, respectively. Many 446 studies have shown that, VSL in fish differs according to species. In Barbus sharpeyi VSL 447 was measured at $11.6 \mu \mathrm{m} \mathrm{sec}^{-1}$ (Kalbasssi et al. 2013), while others have reported $59 \mu \mathrm{m} \mathrm{s}^{-1}$ in 448 Salmo salar (Figueroa et al. 2016), $97 \mu \mathrm{m} \mathrm{s}^{-1}$ to $134 \mu \mathrm{m} \mathrm{s}^{-1}$ in Prochilodus lineatus (Viveiros 
and Leal 2016; Viveiros et al. 2017), $57 \mu \mathrm{m} \mathrm{s}^{-1}$ in rainbow trout Oncorhynchus mykiss

450 (Suquet et al. 2012b) and $150 \mu \mathrm{m} \mathrm{s}^{-1}$ in Siberian sturgeon Acipenser baerii spermatozoa 451 (Sarosiek et al. 2014). VSL of sea urchin spermatozoa was shown to be $170-240 \mu \mathrm{m} \mathrm{sec}^{-1}$ in 452 Hemicentrotus pulcherrimus (Hiramoto and Baba 1978) and 150-200 $\mu \mathrm{m} \mathrm{sec}^{-1}$ in 453 Paracentrotus lividus (Fabbrocini and D'Adamo 2017). The factors contributing to the 454 relatively low velocity observed for black-lip pearl oyster in our study may be twofold: firstly, 455 the activation of oyster sperm motility and its duration is associated with internal 456 concentration of cAMP (Demoy-Schneider et al. 2014) under internal pH control (Boulais et 457 al. 2018). Maximum sperm velocity may not have been reached in our assay conditions, 458 although only 4 min separated the transfer to the swimming solution and the first video 459 records. Secondly, the movement of oyster spermatozoa is erratic (Swann 1975) and cells 460 frequently change the plane of their swimming path (Demoy-Schneider et al. 2014). These 461 features contribute to challenges and possible underestimation of velocity values. However, 462 the conditions for velocity estimates were the same for fresh and frozen/thawed sperm 463 samples.

464 Linearity in cryopreserved black-lip pearl oyster spermatozoa was not significantly 465 different from fresh. This is in accordance with the results obtained for Acipenser ruthenus, 466 in which LIN decreased slightly from 0.55 to 0.51 (Psenicka et al. 2008) and for Atlantic cod 467 Gadus morhua L., in which LIN was not significantly modified by cryopreservation (Butts et 468 al. 2011). Our results indicated that sperm cells that survived the freeze/thaw process 469 presented some defects that induce slight perturbations in swimming ability compared to the $470 \quad$ non-treated samples. 
474 respiratory activity, ATP content and creatine kinase activity was significantly affected by the cryopreservation process. Compared to fresh sperm, a significant $88 \%$ lower respiration rate was observed in frozen/thawed sperm. This difference may be explained by the discrepancy in 477 the percent of active cells. Motile spermatozoa should present a high mitochondrial 478 respiration rate, allowing high ATP production. It was demonstrated in sea urchin (Tombes 479 and Shapiro 1985, 1989; Tombes et al. 1987; Walliman et al. 2011; Ingermann et al. 2011) 480 that creatine-phosphate stores and creatine kinase activity are related the flagellar motility 481 (Saudrais et al. 1998; Dzyuba et al. 2017; Fedorov et al. 2017). van Dorsten et al. (1997) 482 showed that, in sea urchin sperm, creatine kinase activity is related to energy metabolism $\left(\mathrm{O}_{2}\right.$ 483 consumption and ATP production).

484 The initial ATP content was low in black-lip pearl oyster $\left(5 \mathrm{nmol} / 10^{9}\right.$ spermatozoa $)$ compared 485 to Pacific oyster (45 nmol/10 ${ }^{9}$ spermatozoa) (Suquet et al. 2010) and great scallop (203 $486 \mathrm{nmol} / 10^{9}$ spermatozoa) (Suquet et al. 2016). This low ATP content may partly explain the low 487 velocity values observed for black-lip pearl oyster sperm. The cryopreservation process 488 resulted in $85 \%$ lower ATP content in thawed spermatozoa using $\mathrm{DCSB}_{4}$ as activating 489 medium, as previously observed (Demoy-Schneider et al. 2014). This was in correlation with 490 the reduction in mitochondrial respiration. One interpretation is that most of the initial ATP 491 content is used to sustain sperm swimming, even for frozen/thawed spermatozoa which 492 contained low ATP levels. A similar decrease was reported in Pacific oyster (Suquet et al. 493 2010), but in great scallop, no significant difference in intracellular sperm ATP content was 494 observed between fresh and frozen/thawed sperm (Suquet et al. 2016). We found 495 cryopreservation to be associated with a $27.5 \%$ lower creatine kinase activity black-lip pearl 496 oyster spermatozoa compared to fresh. It was also shown that enzyme activity, including 497 creatine kinase activity, was involved in flagellar mobility and thus represents an indicator of 
sperm quality, as reported in sea urchin (Tombes and Shapiro 1985, 1989; Wallimann et al. 1986; Tombes et al. 1987; Wallimann and Hemmer 1994; van Dorsten et al. 1997; Wallimann et al. 2011), rainbow trout $O$. mykiss (Saudrais et al. 1998) and sturgeon A. ruthenus (Fedorov et al. 2017). Cryopreservation has been reported to affect enzyme activity in marine fish. Actually, Li et al. (2010b) observed alterations of enzyme activity involved in metabolism of C. carpio frozen/thawed spermatozoa. Butts et al. (2011) reported a decrease in anti-trypsin 504 activity in Atlantic cod frozen/thawed spermatozoa and Zilli et al. (2004) observed an increase of malate dehydrogenase activity in sea bass Dicentrarchus labrax frozen/thawed spermatozoa, but did not observe change in activity of $\beta$-aspartate aminotransferase, isocitrate dehydrogenase or $\beta$ - D glucuronidase. This decrease in enzyme activity, combined with lower

508 mitochondrial respiration could explain why the ATP content is lower in frozen/thawed black-

509 lip pearl oyster spermatozoa, as these metabolic processes could be limiting for an efficient cellular ATP supply (Cosson, 2012) in fish spermatozoa.

\section{Conclusion}

514 The present work was an opportunity to use a panel of quality criteria to ensure integrity, motility and the energy stores prior to cryopreservation to assist in selection of the welladapted samples of black-lip pearl oyster sperm to cryopreservation. The descriptive analysis

517 is essential to optimize the success rate of cryopreservation and in vitro fertilization. The 518 simplest and most rapid parameter to be studied is the percent motility in the alkaline 519 activating medium $\mathrm{DSCB}_{4}$. The results we obtained showed that motility measurements can 520 be used as a predictive possibility for future application of cryopreservation in this species. 521 Ultimately, fertilization tests must be conducted to confirm the success of sperm 522 cryopreservation in P. margaritifera. 


\section{Acknowledgments}

525

This work was supported by the French Ministère des Outremers and conducted under the research program "La cryoconservation des spermatozoïdes de l'huître perlière Pinctada margaritifera, un atout pour une perliculture durable et la sauvegarde de sa biodiversité". Black-lip pearl oysters $P$. margaritifera were kindly provided by the Direction des Ressources Marines et Minières of French Polynesia. The ATP concentration measurements were carried out in the Laboratoire d'Analyses Médicales of the Centre Hospitalier de la Polynésie française in French Polynesia with the helpful collaboration of Rodolphe BADIN. The authors are grateful to Michel RODIÈRE (UPF) for his help regarding the statistical analysis and to Kathleen HILLS and Alan PIKE (Lucidus Consultancy) for reviewing the English.

\section{References}

Aberkane, B., Iguer-ouada, M., 2016. Sperm motility parameters of Barbus barbus callensis throughout the reproduction season: computer aided semen analysis and gametes motility duration. Iran. J. Fish. Sci. 15, 1556-1567.

Acosta-Salmón, H., Jerry, D.R., Southgate, P.C., 2007. Effects of cryoprotectant agents and freezing protocol on motility of black-lip pearl oyster (Pinctada margaritifera L.) spermatozoa. Cryobiology. 54, 13-18.

Adams, S.L., Hessian, P.A., Mladenov P.V., 2004a. Cryopreservation of sea urchin (Evechinus chloroticus) sperm. CryoLetters. 25, 287-300.

Adams, S.L., Smith, J.F., Roberts, R.D., Janke, A.R., Kaspar, H.F., Tervit, H.R., Pugh, P.A., Webb, S.C., King N.G., 2004b. Cryopreservation of sperm of the Pacific oyster (Crassostrea gigas): development of a practical method for commercial spat production. Aquaculture. 242, 271-282.

Amann, R.P., Waberski, D., 2014. Computer-assisted sperm analysis (CASA): capabilities and potential developments. Theriogenology. 81, 5-17. 
Arnaud-Haond, S., Vonau, V., Bonhomme, F., Boudry, P., Blanc, F., Prou, J., Seaman, T., Goyard, E., 2004. Spatio-temporal variation in the genetic composition of wild populations of pearl oyster (Pinctada margaritifera cumingii) in French Polynesia following 10 years of juvenile translocation. Molec; Ecology. 13, 2001-2007.

561

562

563

564

565

566

567

568

569

570

571

572

573

574

575

576

577

578

579

580

581

582

583

584

585

586

587

588

589

590

591

592

593

594

595

596

597

598

599

600

601

602

603

604

Asturiano, J.F., Marco-Jiménez, M., Peñaranda, D.S., Garzón, D.L., Pérez, L., Vicente, J.S., Jover M., 2007. Effect of sperm cryopreservation on the european eel sperm viability and spermatozoa morphology. Reprod. Dom. Anim. 42, 162-166.

Bacou, F., 1972. Evolution quantitative et qualitative de la créatine kinase chez le lapin au cours des périodes fœtale et néonatale. Ann. Biol. Anim. Bioch. Biophys. 12, 581-588.

Bougrier, S., Rabenomanana, L.D., 1986. Cryopreservation of spermatozoa of the Japanese oyster, Crassostrea gigas. Aquaculture. 58, 277-280.

Boulais, M., Soudant, P., Le Goïc, N., Quéré, C., Boudry, P., Suquet, M., 2015. Involvement of mitochondrial activity and OXPHOS in ATP synthesis during the motility phase of spermatozoa in the Pacific oyster, Crassostrea gigas. Biol. Reprod. 93, 1-7.

Boulais, M., Soudant, P., Le Goïc, N., Quéré, C., Boudry, P., Suquet, M., 2017. ATP content and viability of spermatozoa drive variability of fertilization success in the Pacific oyster (Crassostrea gigas). Aquaculture. 479, 114-119.

Boulais, M., Suquet, M., Arsenault-Pernet, M.E.J., Malo, F., Queau, I., Pignet, P., Ratiskol, D., Le Grand, J., Huber, M., Cosson, J., 2018. Change of pH triggers sperm motility in the Pacific oyster (Crassostrea gigas). Biology Open. 7, doi: 10.1242/bio.031427.

Butts, I.A.E., Babiak, I., Ciereszko, A., Litvak, M.K., Słowińska, M., Soler, C., Trippel, E.A., 2011. Semen characteristics and their ability to predict sperm cryopreservation potential of Atlantic cod, Gadus morhua L. Theriogenology. 75, 1290-1300.

Cosson, J., Huitorel, P., Gagnon, C., 2003. How spermatozoa come to be confined to surfaces. Cell Mot. Cytoskel. 54, 56-63.

Cosson, J., Groison, A.L., Suquet, M., Fauvel, C., Dreanno, C., Billard, R., 2008a. Studying sperm motility in marine fish: an overview on the state of the art. J. Appl. Ichthyol. 24, 460486.

Cosson, J., Groison, A.L., Suquet, M., Fauvel, C., Dreanno, C., Billard, R., 2008b. Marine fish spermatozoa: racing ephemeral swimmers. Reproduction. 136, 277-294.

Cosson, J., 2012. ATP, the sperm movement energizer, in: Kuestler, E., Traugott, G. (Eds.), Adenosine Triphosphate: chemical properties, biosynthesis and functions in cells". Nova Publishers Inc., New York, pp. 1-46.

Dawson, D.M., Eppenberger, H.M., Eppenberger, M.E., 1965. Creatine kinase: evidence for a dimeric structure. Biochem. Biophys. Res. Commun. 21, 343-353. 
Demoy-Schneider, M., Levêque, A., Schmitt, N., Cosson, J., Le Pennec, M., 2012. Motility activation and metabolism characteristics of spermatozoa of the black-lip pearl oyster Pinctada margaritifera var: cumingii (Jameson, 1901). Theriogenology. 77, 53-64.

Demoy-Schneider, M., Schmitt, N., Suquet, M., Labbé, C., Boulais, M., Prokopchuk, G., Cosson, J., 2014. Biological characteristics of sperm in two oyster species: the Pacific Oyster, Crassostrea gigas, and the black-lip-pearl o yster, Pinctada Margaritifera. in: Erickson, B.T., (Eds.), Spermatozoa, biology, motility and function and chromosomal abnormalities. Nova Science Publishers Inc., New York, pp. 15-75.

Di Matteo, O., Langellotti, A.L, Masullo, P., Sansone, G., 2009. Cryopreservation of the Mediterranean mussel (Mytilus galloprovincialis) spermatozoa. Cryobiology. 58, 145-150.

Dong, Q., Huang, C., Eudeline, B., Tiersch, T.R., 2005. Systematic factor optimization for cryopreservation of shipped sperm samples of diploid Pacific oysters, Crassostrea gigas. Cryobiology. 51, 176-197.

Dzyuba, B., Bondarenko, O., Gazo, I., Prokopchuk, G., Fedorov, P., Cosson, J., 2017. Energetics of fish spermatozoa: the proven and the possible. Aquaculture. 472, 60-72.

Espinoza, C., Valdivia, M., Dupré, E., 2010. Morphological alterations in cryopreserved spermatozoa of scallop Argopecten purpuratus. Lat. Am. J. Aquat. Res. 39, 121-128.

Fabbrocini, A., d'Adamo, R., 2017. Motility of sea urchin Paracentrotus lividus spermatozoa in the post-activation phase. Aquac. Res. 48, 5526-5532.

Fedorov, P., Grabic, R., Fedorova, G., Cosson, J., Boryshpolets, S., Dzyuba, B., 2017. Development and application of LC/HRPS for quantification of adenine nucleotides, creatine phosphate, and creatine in sturgeon spermatozoa. Czech. J. Anim. Sci. 62, 67-74.

Figueroa. E., Valdebenito, I., Merino, O., Ubilla, A., Risopatrón, J., Farias J.G., 2016. Cryopreservation of Atlantic salmon Salmo salar sperm: effects on sperm physiology. J. Fish. Biol. 89, 1537-1550.

Gwo, J.C., Chen, C.W., Cheng, H.Y., 2002. Semen cryopreservation of small abalone (Haliotis diversicolor supertexa). Theriogenology. 58, 1563-1578.

Gwo, J.C., Wu, C.Y., Chang, W.S., Cheng, H.Y., 2003. Evaluation of damage in Pacific oyster (Crassostrea gigas) spermatozoa before and after cryopreservation using comet assay. CryoLetters. 24, 171-180.

Hiramoto, Y., Baba S.A., 1978. A quantitative analysis of flagellar movement in echinoderm spermatozoa. J. Exp. Biol. 76, 85-104.

Holt, W.V., Van Look, K.J.W., 2004. Concepts in sperm heterogeneity, sperm selection and sperm competition as biological foundations for laboratory tests of semen quality. Reproduction. 127, 527-535. 
654 Cryopreservation of sperm and larvae of the European flat oyster (Ostrea edulis). J. Appl. Ichtyol. 28, 948-951.

Hui, B., Demoy-Schneider, M., Vonau, V., Le Moullac, G., Moriceau, J., Le Pennec, M., Cochard, J.C., 2009. Gamete cryopreservation, an asset for a durable pearl farming in French Polynesia. Proceedings of the $11^{\text {th }}$ Pacific Science Inter-congress, Tahiti, 2-6 March, isbn $n^{\circ}$ 978-2-11-098964-2.

661

662

663

664

665

666

667

668

669

670

671

672

673

674

675

676

677

678

679

680

681

682

683

684

685

686

687

688

689

690

691

692

693

694

695

696

697

698

699

700

Hui, B., Vonau, V., Moriceau, J., Tetumu, R., Vanaa, V., Demoy-Schneider, M., Suquet, M., Le Moullac, G., 2011. Hatchery-scale trials using cryopreserved spermatozoa in black-lip pearl oyster (Pinctada margaritifera). Aquat. Living Resour. 24, 219-223.

Ingermann, R.L., Schultz, C.L., Kanuga, M.K., Wilson-Leedy, J.G., 2011. Metabolism of motile zebrafish sperm. Comp. Biochem. Physiol. Mol. Integr. Physiol. 158, 461-467.

Kalbassi, M.R., Lorestani, R., Ghafli Maramazi, J., 2013. Analysis of saline activator solution effects on sperm quality indices on Barbus sharpeyi by Image J software. Iran. J. Fish. Sci. $12,357-377$.

Kawamoto, T., Narita, T., Isowa, T., Aoki, H., Havashi, M., Komaru, A., Otha, H., 2007. Effects of cryopreservation methods on post thaw motility of spermatozoa from the Japanese pearl oyster, Pinctada fucata martensii. Cryobiology. 54, 19-26.

Ky, C.L., Le Pabic, L., Sham Koua, M., Molinari, N., Nakasai, S., Devaux, D., 2017. Is pearl colour from Pinctada margaritifera predictable through shell phenotypes and rearing environments selections? Aquac. Res. 48, 1041-1057.

Kurokura, H., Namba, K., Ishikawa, T., 1990. Lesions of spermatozoa by cryopreservation in oyster Crassostrea gigas. Nippon Suisan Gakk. 56, 1803-1806.

Li, P., Li, Z.H., Dzyuba, B., Hulak, M., Rodina, M., Linhart, O., 2010a. Evaluating the impacts of osmotic and oxidative stress on common carp (Cyprinus carpio, L.) sperm caused by cryopreservation techniques. Biol. Reprod. 83, 852-858.

Li, P., Hulak, M., Koubek, P., Sulc, M., Dzyuba, B., Boryshpolets, S., Rodina, M., Gela, D., Manaskova-Postlerova, P., Peknicova, J., Linhart O., 2010b. Ice-age endurance : the effects of cryopreservation on proteins of sperm of common carp, Cyprinus carpio L. Theriogenology. 74, 413-423.

Linhart, O., Rodina, M., Flajšhans, M., Gela, D., Kocour, M., 2005. Cryopreservation of European catfish Silurus glanis sperm: sperm motility, viability, and hatching success of embryos. Cryobiology. 51, 250-261.

Liu, B., Liu, Y., Liu, S., Xu, T., Liu, Q., Li, X., 2016. Cryopreservation of stripped spawned sperm using non-programmable freezing technique in the blue mussel Mytilus galloprovincialis. Aquac. Res. 47, 3888-3898. 
Lowry, O.H., Rosenbrough, N.J., Farr, A.L., Randall, R.J., 1951. Protein measurement with the Folin phenol reagent. J. Biol. Chem. 193, 265-275.

Lyons, L., Jerry, D.R., Southgate, P.C., 2005. Cryopreservation of black-lip pearl oyster (Pinctada margaritifera) spermatozoa : effects of cryoprotectants on spermatozoa motility. J. Shellfish Res. 24, 1187-1190.

Martínez-Páramo, S., Horváth, Á., Labbé, C., Zhang, T., Robles, V., Herráez, P., Suquet, M., Adams, S., Viveiros, A., Tiersch, T.R., Cabrita, E. 2017. Cryobanking of aquatic species. Aquaculture. 472, 156-177.

Merino, O., Risopatróna, J., Sánchez, R., Isachenkod, E., Figueroa, E., Valdebenito, I., Isachenkod, V., 2011. Fish (Oncorhynchus mykiss) spermatozoa cryoprotectant-free vitrification: Stability of mitochondrion as criterion of effectiveness. Anim. Reprod. Sci. 124, $125-131$.

Narita, T., Kawamoto, T., Isowa, K., Aoki, H., Hayashi, M., Komaru, A., Ohta, H., 2007. Effects of cryopreservation methods on post-thaw motility of spermatozoa from the Japanese pearl oyster, Pinctada fucata martensii. Cryobiology. 54, 19-26.

Narita, T., Kawamoto, T., Isowa, K., Aoki, H., Hayashi, M., Komaru, A., Ohta, H., 2008. Fertility of cryopreserved spermatozoa of the Japanese pearl oyster, Pinctada fucata martensii. Aquaculture. 275, 178-181.

Pacey, A., Bentley, M., 1993. Agonists of sperm maturation in Arenicola marina (Annelida: Polychaeta) increase the oxygen consumption of sperm suspensions in vitro. Invertebr. Reprod. Dev. 24, 27-38.

Paniagua-Chavez, C.G., Buchanan, J.T., Tiersch, T.R., 1998. Effect of extender solutions and dilution on motility and fertilizing ability of Eastern oyster sperm. J. Shellfish Res. 17, 231237.

Paniagua-Chávez, C.G., Tiersch, T.R., 2001. Laboratory studies of cryopreservation of sperm and trochophore larvae of the eastern oyster. Cryobiology. 43, 211-223.

Paniagua-Chávez, C.G., Jenkins, J., Segovia, M., Tiersch, T.R., 2006. Assessment of gamete quality for the eastern oyster (Crassostrea virginica) by use of fluorescent dyes. Cryobiology. $53,128-138$.

Pouvreau, S., Tiapari, J., Gangnery, A., Lagarde, F., Garnier, M., Teissier, H., Haumani, G., Buestel, D., Bodoy, A., 2000. Growth of the black-lip pearl oyster, Pinctada margaritifera, in suspended culture under hydrobiological conditions of Takapoto lagoon (French Polynesia). Aquaculture. 184, 133-154.

Psenicka, M., Dietrich, G.J., Wojtczak, M., Nynca, J., Rodina, M., Linhart, O., Cosson, J., Ciereszko, A., 2008. Acrosome staining and motility characteristics of sterlet spermatozoa after cryopreservation with use of methanol and DMSO. Cryobiology. 56, 251-253. 
Riesco, M.F., Félix, F., Matias, D., Joaquim, S., Suquet, M., Cabrita, E., 2017. First study in cryopreserved Crassostrea angulata sperm. Gen Comp Endocrinol. 245, 108-115.

Sarosiek, B., Glogowski, J., Cejko, B.I., Kujawa, R., Szczepkowski, Kuźmiński, H., Dobosz, S., Kowalski, R.K., 2014. Inhibition of $\beta$-N-acetylglucosaminidase by acetamide affects sperm motility and fertilization success of rainbow trout (Oncorhynchus mykiss) and Siberian sturgeon (Acipenser baerii). Theriogenology. 81, 723-732.

Saudrais, C., Fierville, F., Loir, M., Le Rumeur, E., Cibert, C., Cosson, J., 1998. The use of phosphocreatine plus ADP as energy source for motility of membrane-deprived trout spermatozoa. Cell Motil. Cytoskeleton. 41, 91-106.

Shaliutina-Kolešová, A., Cosson, J., Lebeda, I., Gazo, I., Shaliutina, O., Dzyuba, B., Linhart, O., 2015. The influence of cryoprotectants on sturgeon (Acipenser ruthenus) sperm quality, DNA integrity, antioxidant responses, and resistance to oxidative stress. Anim. Reprod. Sci. 159, 66-76.

Suquet, M., Labbé, C., Brizard, R., Donval, A., Le Coz, J.R., Quéré, C., Haffray, P., 2010. Changes in motility, ATP content, morphology and fertilization capacity during the movement phase of tetraploid Pacific oyster (Crassostrea gigas) sperm. Theriogenology. 74, 111-117.

Suquet, M., Le Mercier, A., Rimond, F., Mingant, C., Haffray, P., Labbé, C., 2012a. Setting tools for the early assessment of the quality of thawed Pacific oyster (Crassostrea gigas) Dlarvae. Theriogenology. 78, 462-467.

Suquet, M., Cosson, J., Donval, A., Labbé, C., Bernard, I., Fauvel, C., 2012b. Marathon versus sprint racers: an adaptation of sperm characteristics to the reproductive strategy of Pacific oyster, turbot and seabass. J. Appl. Ichthyol. 28, 956-960.

Suquet, M., Gourtay, C., Donval, A., Le Goïc, N., Quéré, C., Malo, F., Le Grand, J., Ratiskol, D., Mingant, C., Fauvel, C., 2016. The quality of great scallop (Pecten maximus) sperm after thawing. Gen. Comp. Endocrinol. 229, 127-131.

Swann, M.A., 1975. The propulsion of the non-rotating ram and oyster spermatozoa. Biol. Rep. 13, 17-29.

Tombes, R.M., Shapiro, B.M., 1985. Metabolite channeling: a phosphorylcreatine shuttle to mediate high energy phosphate transport between sperm mitochondrion and tail. Cell. 41, 325-334.

Tombes, R.M., Brokaw, C.J., Shapiro, B.M., 1987. Creatine kinase-dependent energy transport in sea urchin spermatozoa. Flagellar wave attenuation and theoretical analysis of high energy phosphate diffusion. Biophys. J. 52, 75-86.

Tombes, R.M., Shapiro, B.M., 1989. Energy transport and cell polarity: relationship of phosphagen kinase activity to sperm function. J. Exp. Zool. 251, 82-90. 
van Dorsten, F.A., Wyss, M., Wallimann, T., Nicolay, K., 1997. Activation of sea-urchin sperm motility is accompanied by an increase in the creatine kinase exchange flux. Biochem. J. 325, 411-416.

Viveiros A.T., Leal M.C., 2016. Sperm dilution ratio affects post-thaw motility rate and velocity of Prochilodus lineatus (Characiformes) sperm. Zygote. 24, 662-667.

Viveiros A.T., Di Chiacchio I.M., Almeida I.L., Taffarel T.R., Leal M.C., 2017. Storage and transportation of Prochilodus lineatus (Characiformes) sperm prior to cryopreservation. Gen. Comp. Endocrinol. 245, 84-88.

Wallimann, T., Moser, H., Zurbriggen, B., Wegmann, G., Eppenberger, H.M., 1986. Creatine kinase isoenzymes in spermatozoa. J. Muscle Res. Cell Motil. 7, 25-34.

Wallimann, T., Hemmer, W., 1994. Creatine kinase in non-muscle tissues and cells. Mol. Cell. Biochem. 133-134, 193-220.

Wallimann, T., Tokarska-Schlattner, M., Schlattner, U., 2011. The creatine kinase system and pleiotropic effects of creatine. Amino Acids. 40, 1271-1296.

Wilson-Leedy, J.G., Ingermann, R.L., 2007. Development of a novel C.A.S.A. system based on open source software for characterization of zebrafish sperm motility parameters. Theriogenology. 67, 661-672.

Yang, H., Hu, E., Cuevas-Uribe, R., Supan, J., Guo, X., Tiersch, T., 2012. High-thoughput sperm cryoconservation of eastern oyster Crassostrea virginica. Aquaculture. 344-349, 223230.

Yankson, K., Moyse, J., 1991. Cryopreservation of the spermatozoa of Crassostrea tulipa and other three oysters. Aquaculture. 97, 259-267.

Yurchenko, O., 2012. Comparative ultrastructural study of spermatozoa in some oyster species from the Asian-Pacific Coast. Micron. 43, 365-373.

Zilli, L., Schiavone, R., Zonno, V., Storelli, C., Vilella, S., 2004. Adenosine triphosphate concentration and $\beta-\mathrm{D}$ glucuronidase activity as indicators of sea bass semen quality. Biol. Reprod. 70, 1679-1684.

Tables

\section{Table 1}

Calibration parameters applied to determine concentration and morphological characteristics of spermatozoa using the Image $\mathbf{J}$ software (Wilson-Leedy and Ingermann 2007). 


\begin{tabular}{|l|l|}
\hline Parameters & Values \\
\hline Counting surface $\left(\mathrm{mm}^{2}\right)$ & 0.05 \\
\hline Scale (pixels $\left./ \mathrm{mm}^{2}\right)$ & 6000 \\
\hline Minimum sperm size (pixels) & 1 \\
\hline Maximum sperm size (pixels) & 40 \\
\hline Circularity & $0-1$ \\
\hline
\end{tabular}

Table 2

849 Sperm tracking values applied in the dialog box generated by CASA within Image J

850 according to Wilson-Leedy and Ingermann (2007). Values were adapted to Pinctada

851 margaritifera sperm for sperm path construction and determination of motility of fresh and

852 frozen/thawed spermatozoa. VSL = straight line velocity, VAP = velocity of average path,

$853 \mathrm{VCL}=$ curvilinear velocity, $\mathrm{WOB}=$ wobble and $\mathrm{LIN}=$ linearity.

854

\begin{tabular}{|l|r|}
\hline Parameters & Values \\
\hline Minimum sperm size (pixels) & 0 \\
\hline Maximum sperm size (pixels) & 40 \\
\hline Minimum track length (frames) & 25 \\
\hline Maximum sperm velocity between frames (pixels) & 15 \\
\hline Minimum VSL for motile sperm $\left(\mu \mathrm{m} \mathrm{sec}^{-1}\right)$ & 2 \\
\hline Minimum VAP for motile sperm $\left(\mu \mathrm{mec}^{-1}\right)$ & 5 \\
\hline
\end{tabular}




\begin{tabular}{|l|r|}
\hline Minimum VCL for motile sperm $\left(\mu \mathrm{m} \mathrm{sec}^{-1}\right)$ & 8 \\
\hline Low VAP speed $\left(\mu \mathrm{m} \mathrm{sec}^{-1}\right)$ & 5 \\
\hline Maximum percent of path with zero VAP & 1 \\
\hline Maximum percent of path with low VAP & 50 \\
\hline Low VAP speed $2\left(\mu \mathrm{m} \mathrm{sec}^{-1}\right)$ & 8 \\
\hline Low VCL speed $\left(\mu \mathrm{m} \mathrm{sec}^{-1}\right)$ & 10 \\
\hline High WOB (percent VAP/VCL) & 80 \\
\hline High LIN (percent VSL/VAP) & 80 \\
\hline High WOB 2 (percent VAP/VCL) & 200 \\
\hline High LIN 2 (percent VSL/VAP) & 200 \\
\hline Frame rate (frame sec & -1 \\
\hline Microns per 1000 pixels & 25 \\
\hline
\end{tabular}

856

Table 3

866 Effect of the cryopreservation on morphological characteristics of black-lip pearl oyster

868 frozen/thawed samples. Different superscripts indicate significant differences $(P<0.05)$

869 between fresh and frozen/thawed spermatozoa.

870

\begin{tabular}{|l|c|c|}
\hline \multicolumn{1}{|c|}{ Morphological characteristic } & Fresh spermatozoa & Frozen-thawed spermatozoa \\
\hline Area $\left(\mu \mathrm{m}^{2}\right)$ & $3.41 \pm 0.18^{\mathrm{a}}$ & $1.31 \pm 0.08^{\mathrm{b}}$ \\
\hline
\end{tabular}




\begin{tabular}{|l|c|c|}
\hline Crofton perimeter $(\mu \mathrm{m})$ & $7.08 \pm 0.22^{\mathrm{c}}$ & $4.30 \pm 0.14^{\mathrm{d}}$ \\
\hline Feret diameter $(\mu \mathrm{m})$ & $2.45 \pm 0.06^{\mathrm{e}}$ & $1.590 \pm 0.053^{\mathrm{f}}$ \\
\hline Circularity & $0.87 \pm 0.03^{\mathrm{g}}$ & $0.85 \pm 0.03^{\mathrm{g}}$ \\
\hline Feret perimeter/Crofton perimeter & $0.346 \pm 0.004^{\mathrm{h}}$ & $0.369 \pm 0.004^{\mathrm{h}}$ \\
\hline
\end{tabular}

871

872

873

874

875

876

877

878

879

880

881

882

Table 4

883

Effect of cryopreservation on black-lip pearl oyster sperm movement. Motility

884 parameters were measured using computer-assisted sperm analyzer (CASA) plug-in, for

885 Image $\mathrm{J}$ software (Wilson-Leedy and Ingermann 2007) and adapted to P. margaritifera

886 spermatozoa (see methods). Values represent means \pm SEM, calculated for $\mathrm{n}=28$ fresh samples

887 and $\mathrm{n}=18$ frozen/thawed samples. Different superscripts indicate significant differences $(P<$

888 0.05) between fresh and frozen/thawed spermatozoa. VSL = straight line velocity, VAP =

889 average path velocity and LIN = linearity.

890 
891

\begin{tabular}{|l|c|c|}
\hline \multicolumn{1}{|c|}{ Motility parameter } & Fresh & Frozen-thawed \\
\hline Sperm motility (\%) & $84.7 \pm 3.7^{\mathrm{a}}$ & $54.4 \pm 6.2^{\mathrm{b}}$ \\
\hline VSL $\left(\mu \mathrm{m} \mathrm{sec}^{-1}\right)$ & $66.6 \pm 2.7^{\mathrm{c}}$ & $62.5 \pm 4.8^{\mathrm{c}}$ \\
\hline VAP $\left(\mu \mathrm{m} \mathrm{s}^{-1}\right)$ & $165.7 \pm 7.7^{\mathrm{d}}$ & $131.5 \pm 7.1^{\mathrm{e}}$ \\
\hline LIN $(\%)$ & $40.6 \pm 0.1^{\mathrm{f}}$ & $49.1 \pm 0.1^{\mathrm{f}}$ \\
\hline
\end{tabular}

892

893

894

895

896

897 


\section{Figure captions}

\section{Fig. 1}

\section{Effects of cryopreservation on black-lip pearl oyster spermatozoon morphology by transmission electron microscopy $(n=3)$.}

1a-d : fresh spermatozoon and 1e-h : frozen-thawed spermatozoon. (a) longitudinal section of fresh spermatozoon. $\mathrm{a}=$ acrosome, $\mathrm{dc}=$ distal centriole, $\mathrm{pc}=$ proximal centriole, $\mathrm{f}=$ flagella, $\mathrm{mi}=$ mitochondria, $\mathrm{n}=$ nucleus. (b) cross-section of mid piece, $\mathrm{mi}=$ mitochondria. (c) longitudinal section of acrosome $($ white arrow $=$ dense material, black arrow $=$ flat cap), $\mathrm{a}=$ acrosome, $\mathrm{n}=$ nucleus. (d) longitudinal section of flagellum (white arrow $=$ central microtubules, black arrows $=$ peripheral microtubules), $\mathrm{f}=$ flagella. $(\mathrm{e})$ longitudinal section of frozen/thawed spermatozoon (arrows $=$ lift of plasma membrane), a $=$ acrosome, $\mathrm{mi}=$ mitochondria, $\mathrm{n}=$ nucleus. (f) longitudinal section of spermatozoon (dashed arrow $=$ lift of plasma membrane, white arrow $=$ central microtubules, black arrow $=$ peripheral microtubules), $\mathrm{pc}=$ proximal centriole, $\mathrm{n}=$ nucleus. $(\mathrm{g})$ longitudinal section of acrosome $($ arrow $=$ flat cap disruption), $\mathrm{a}=$ acrosome, $\mathrm{n}=$ nucleus. $(\mathrm{h})$ longitudinal section of frozenthawed spermatozoon (white arrow $=$ central microtubules, black arrows $=$ peripheral microtubules), $\mathrm{f}=$ flagella, $\mathrm{a}=$ acrosome, $\mathrm{mi}=$ mitochondria, $\mathrm{n}=$ nucleus, $\mathrm{pc}=$ proximal centriole, $\mathrm{dc}=$ distal centriole.

\section{Fig. 2}

Effect of cryopreservation on $\boldsymbol{P}$. margaritifera spermatozoon motility. 
Measurements were performed using the CASA. Values represent means \pm SEM calculated for $\mathrm{n}=28$ fresh samples and $\mathrm{n}=18$ frozen/thawed samples. «a» indicates significant difference $(P<0.05)$ between fresh and frozen-thawed sperm.

Fig. 3

Relationship of motility of fresh spermatozoa and frozen/thawed spermatozoa in blacklip pearl oyster $P$. margaritifera. ,

Samples obtained from 18 males were used to assess the motility of fresh and frozen/thawed spermatozoa. Values represent percent motility $\left(y=0.5991 x+3.6926 ; \mathrm{R}^{2}=0.5962 ; P<0.05\right.$; $\mathrm{n}=18)$

Fig. 4

Effect of cryopreservation on sperm metabolism and energetic stock

4a Oxygen consumption of black-lip pearl oyster spermatozoa in alkaline activating solution, $\mathrm{DCSB}_{4}$.

Values represent means \pm SEM calculated for 28 fresh samples and 18 frozen/thawed samples. «a»= significant difference $(P<0.05)$ with/without activation, between fresh and frozenthawed spermatozoa. «b»= significant difference $(P<0.05)$ between fresh and frozen/thawed spermatozoa.

4b ATP content with and without activation in DCSB $_{4}$. 
Values represent means \pm SEM calculated for 28 fresh sperm samples and 18 frozen/thawed samples. $\ll$ a» $=$ significant difference $(P<0.05)$ in ATP content depending on swimming media in fresh and frozen/thawed spermatozoa. «b» $=$ significant difference $(P<0.05)$ between fresh and frozen/thawed sperm.

\section{4c Creatine kinase activity.}

Values represent means \pm SEM calculated for 28 fresh sperm samples and 18 frozen/thawed samples. «a» $=$ significant difference $(P<0.05)$ between fresh and frozen/thawed spermatozoa. 

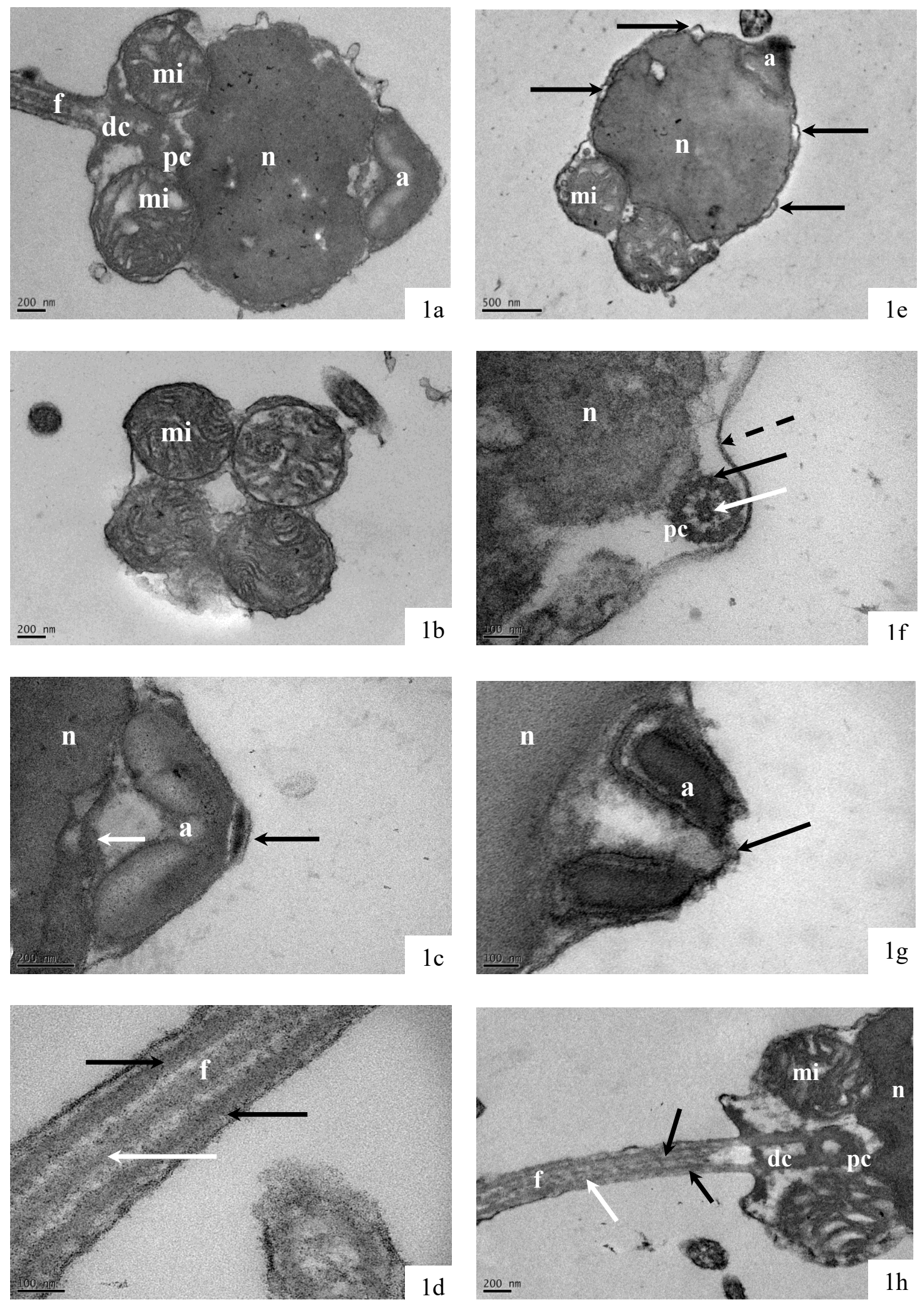


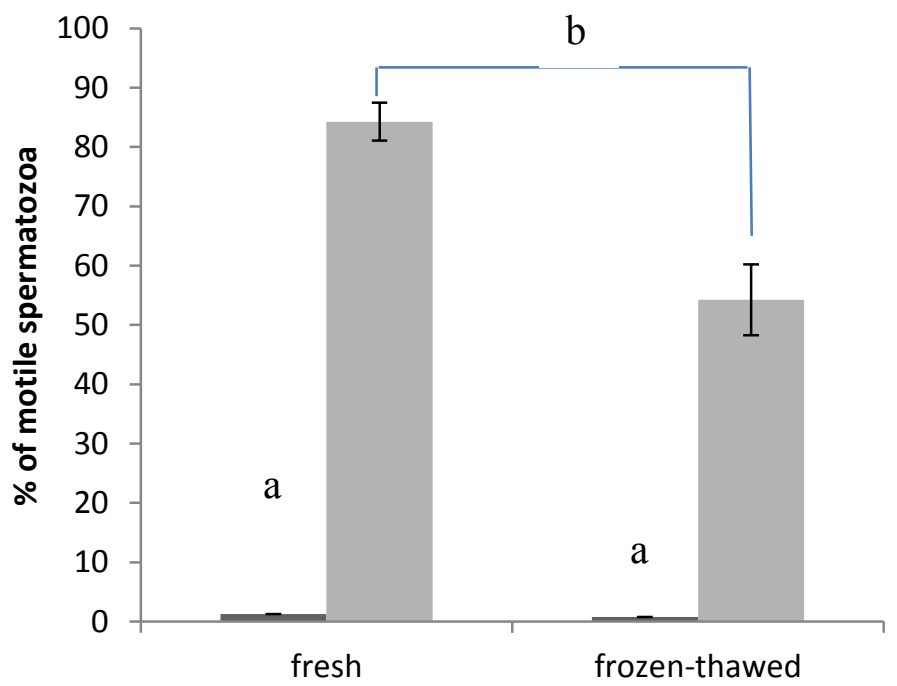

before activation

after activation 


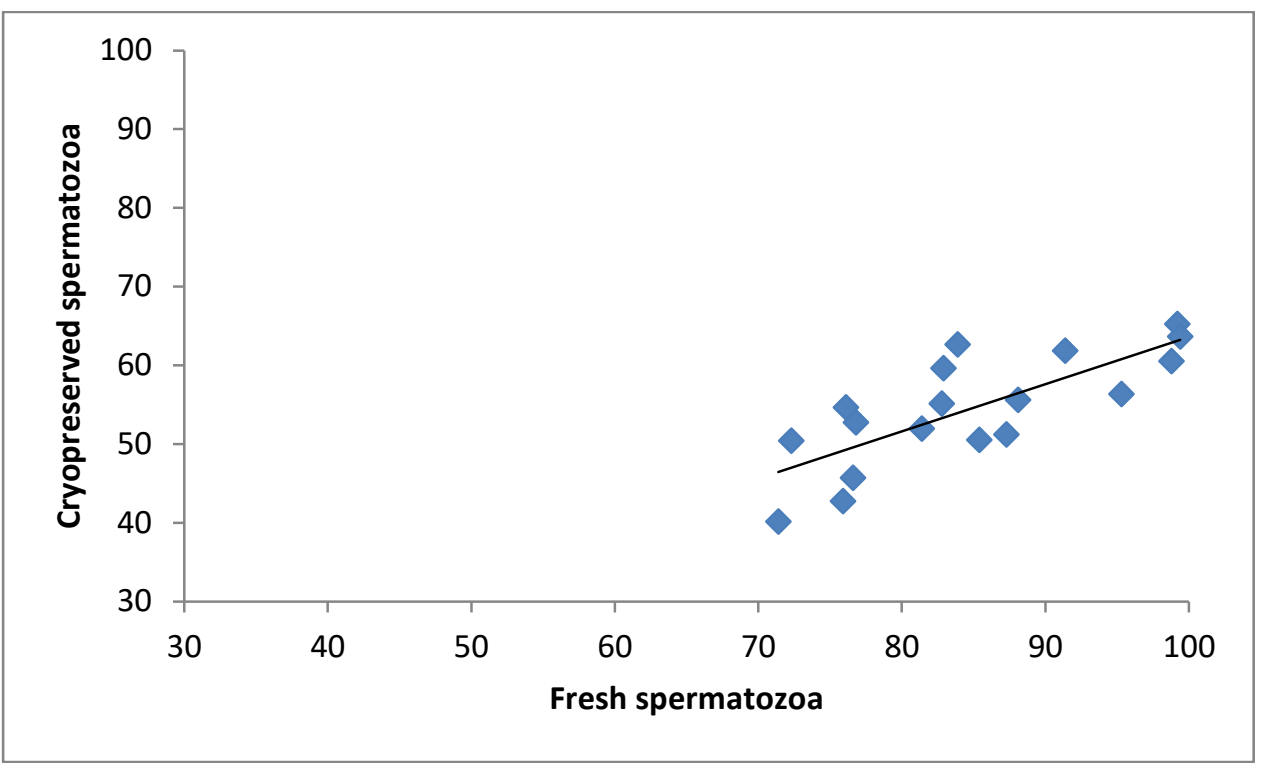


Figure 4a

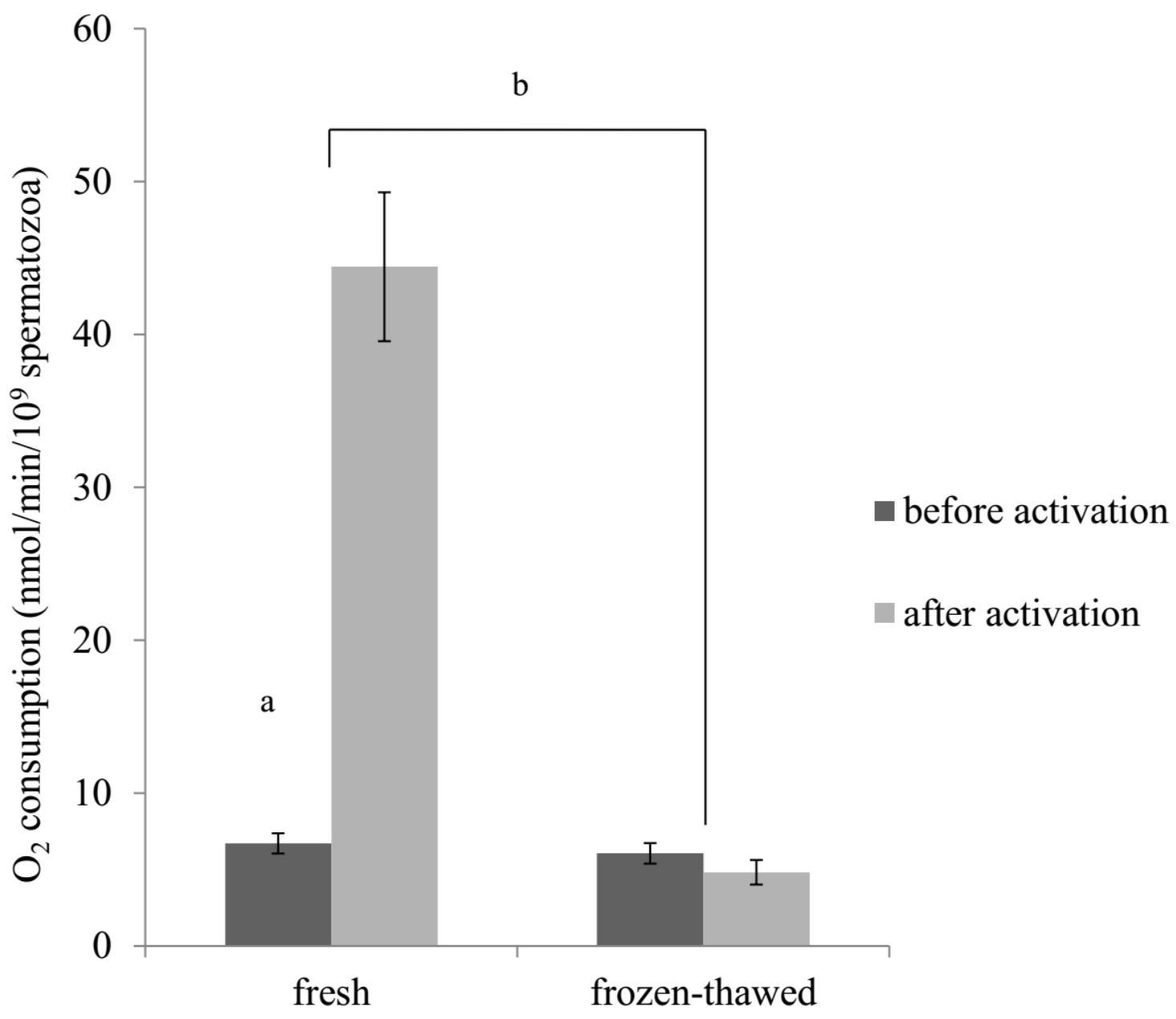


Figure 4b

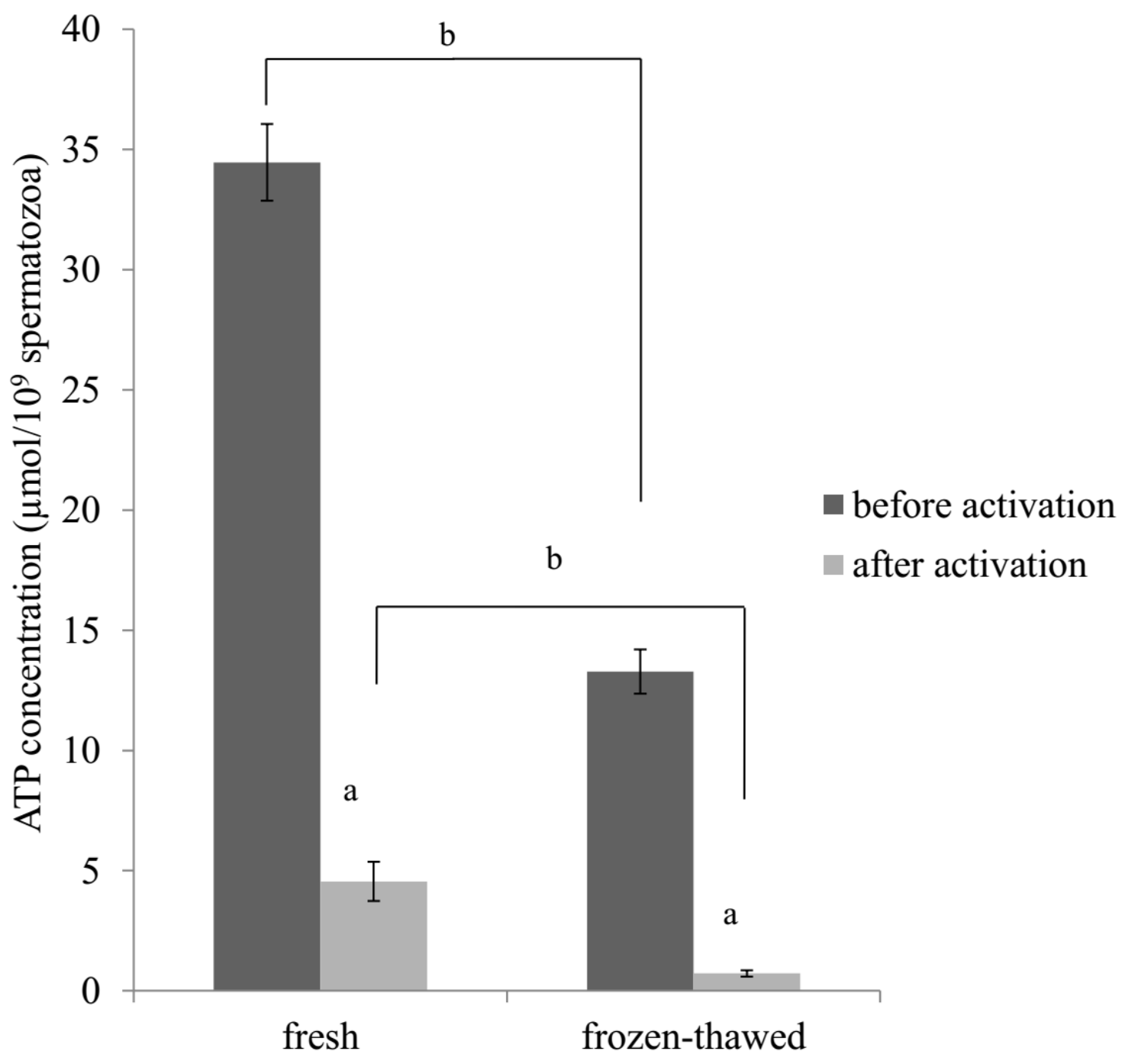


Figure 4c

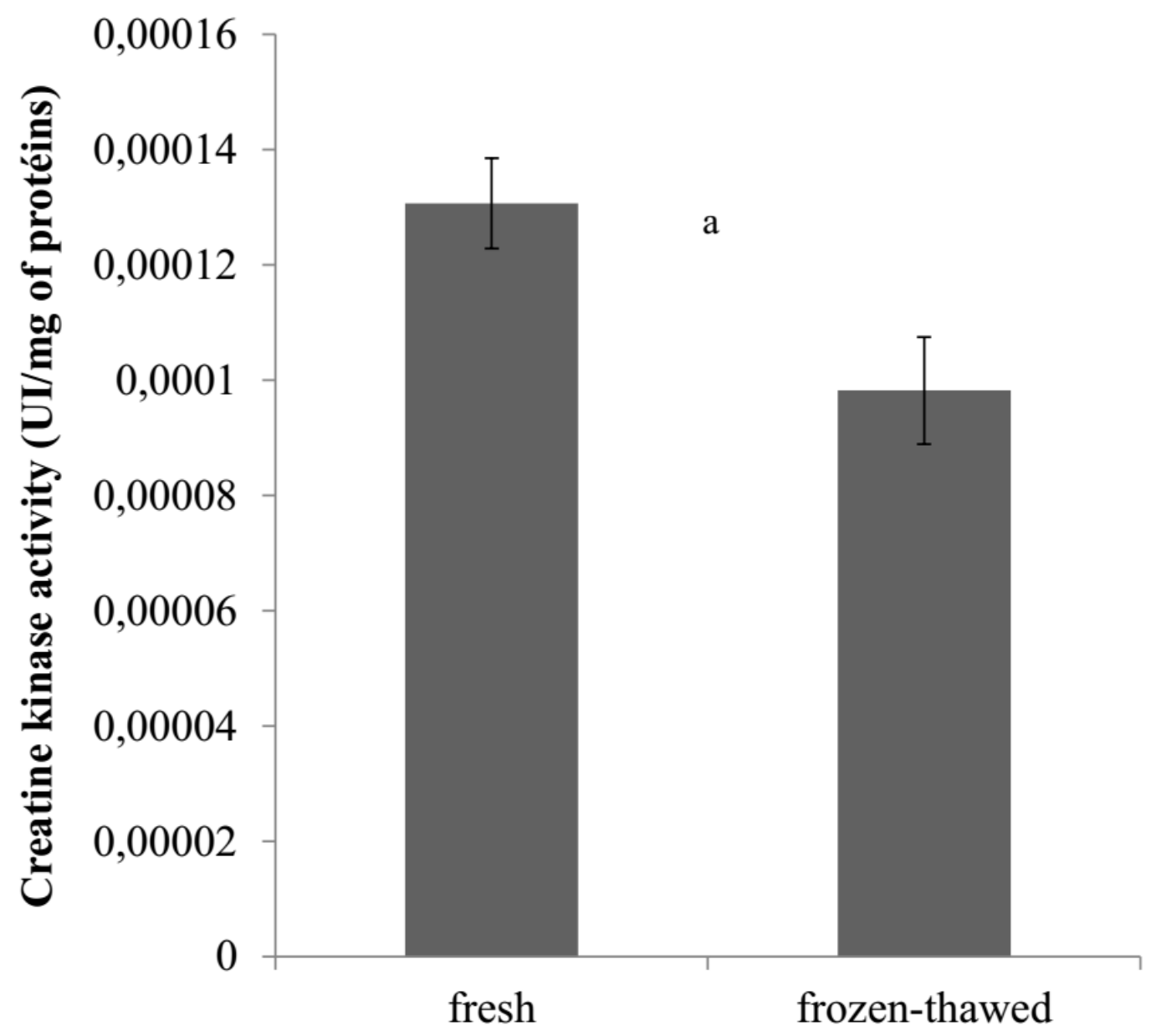

